\title{
The key role of the level of ACE2 gene expression in SARS-CoV-2 infection
}

\author{
Yves Lecarpentier ${ }^{1}$, Alexandre Vallée ${ }^{2, \&}$ \\ ${ }^{1}$ Centre de Recherche Clinique, Grand Hôpital de l'Est Francilien (GHEF), Meaux, France \\ ${ }^{2}$ Department of Clinical Research and Innovation, Foch Hospital, Suresnes, France
}

Correspondence to: Alexandre Vallée; email: alexandre.g.vallee@gmail.com

Keywords: ACE2, Alzheimer's disease, aging, COVID-19, SARS-COV-2

Received: May 14, $2021 \quad$ Accepted: June 5, $2021 \quad$ Published: June 11, 2021

Copyright: (c) 2021 Lecarpentier and Vallée. This is an open access article distributed under the terms of the Creative Commons Attribution License (CC BY 3.0), which permits unrestricted use, distribution, and reproduction in any medium, provided the original author and source are credited.

\begin{abstract}
SARS-CoV-2 more readily affects the elderly, especially as they present co-morbidities. In the COVID-19 pathogeny, ACE2 appears to be the key cell receptor for SARS-CoV-2 to infect humans. The level of ACE2 gene expression influences the susceptibility of contracting SARS-CoV-2. In circumstances in which the ACE2 level is low, the incidence of COVID-19 seems to be fewer. Two clinical patterns illustrate this observation, $i$. e., in infants and in Alzheimer's disease (AD). Very young children and AD patients get little COVID-19, in part probably due to decreased expression of ACE2. The determination of the nasal level of ACE2 gene expression could provide a useful scale to predict the susceptibility to contract the SARS-CoV-2 infection.
\end{abstract}

\section{INTRODUCTION}

The pandemic coronavirus disease-2019 (COVID-19) affect millions of individuals and the severe acute respiratory syndrome coronavirus-2 (SARS-CoV-2) has been shown to be responsible for it. The primary target for entry into host cells has been identified to be the multifunctional protein angiotensin converting enzymerelated carboxypeptidase (ACE2) discovered simultaneously by Donoghue et al. and Tipnis et al. [1, 2]. SARS-CoV-2 more readily affects the elderly [3], especially as they present co-morbidities such as type 2 diabetes, hypertension, chronic obstructive pulmonary disease and cancers [4, 5]. Mortality due to Covid-19 is highly associated with elderly [3]. In COVID patients, the ACE2 protein level significantly increases in both alveolar tissue and bronchial epithelium of diabetic patients [6] and this can partly explain the high rate of infectivity of SARS-CoV-2 in these patients. In hypertensive and diabetic patients treated with ACE inhibitors or angiotensin II type-I receptor blockers (ARBs), an upregulation of ACE2 has been reported [7]. This could facilitate the SARS-CoV-2 infection and increase the risk of developing severe and fatal SARSCoV-2 infection.
In the COVID-19 pathogeny, ACE2 appears to be the key cell receptor for SARS-CoV-2 to infect humans [8-12]. The human coronavirus SARS-CoV-2 binds with its target cells through ACE2, which is largely expressed, particularly in lung, intestine, kidney and blood vessel cells [7]. Thus, SARS-CoV-2 uses its spike protein S1 to enter cells by interacting with the ACE2 receptor on the cell surface membrane. Thus, SARS-CoV-2 acts directly on cells through the ACE2 receptor leading to downregulate the ACE2 expression by binding with the spike (S) viral protein $[8,12,13]$. This decreases the degradation of angiotensin II (Ang-II) into angiotensin1-7 (Ang-(1-7) [14]. ACE2 converts Ang-II to Ang-(1-7) and prevents the effects of the ACE1/angiotensin II axis. AngII induces strong vasoconstriction, inflammatory effects, and profibrotic effects, while Ang-(1-7) exhibits antiproliferative, antiapoptotic, and mild vasodilation and protects against various cardiovascular diseases [15].

The question arises whether the level of ACE2 gene expression influences the susceptibility of contracting SARS-CoV-2. Since SARS-CoV-2 infects the elderly especially as they present co-morbidities with high levels of ACE2 [2], it can be hypothesized that in circumstances in which the ACE2 level is low, the 
incidence of COVID-19 might be fewer. Two clinical patterns make it possible to illustrate this point, i. e., ACE2 level expression in very young infants and in Alzheimer's disease (AD).

\section{DISCUSSION}

\section{SARS-CoV-2 in infants}

In infants compared to adults, numerous studies have highlighted the low rates of SARS-CoV-2 infection [16]. Children account for about $2 \%$ of cases of Covid19 [17]. Children have lower risk of SARS-CoV-2 infection and mortality [18]. Moreover, in the nasal epithelium of the upper airway, a lower ACE2 expression has been recently reported in infants [19]. Importantly, there is an age-dependent ACE2 gene expression in the nasal epithelium which represents the first contact between SARS-CoV-2 and the human body. ACE2 gene expression is lowest in younger infants (aged $<10$ years), and progressively increases with age in older infants (aged 10-17 years), young adults (aged 18-24 years) and adults (aged $>25$ years). The positive and quasi linear relationship between ACE2 gene expression and age appears to be independent of sex and asthma. The lower nasal ACE2 gene expression in children compared to adults may partly explain why SARS-CoV-2 is less prevalent in infants and why they have lower risk of mortality [20].

\section{SARS-CoV-2 in Alzheimer's disease (AD)}

A clinical study has reported that in AD patients with SARS-CoV-2 pneumonia, the duration from hospitalization to discharge has been shown to be shorter and AD-SARS-CoV-2 patients are less likely to report fatigue and present a better prognosis than nonAD SARS-CoV-2 patients [21]. AD patients have a higher clustering onset than non-AD patients. The duration from the onset of symptoms to hospitalization are shorter in AD patients. The role of ACE2 activity in the AD pathophysiology has been reported [22, 23].

In the central nervous system, ACE2 also presents a non-enzymatic function, by hydrolyzing the key peptide amyloid- $\beta$ which plays a key role in the AD pathogenesis. Substrates for ACE2 include amyloid- $\beta$ peptides. ACE2 can efficiently hydrolyze $A \beta 43$ to $A \beta 42$, which is further degraded to the less toxic $A \beta 40$ by ACE [24]. A $\beta 43$ represents a highly amyloidogenic $\mathrm{A} \beta$ peptide that induces plaque formation in the brain. Importantly, ACE2 activity is significantly reduced in the frontal cortex and hypothalamus of OXYS AD rats and in the mid-frontal cortex of AD patients, and this is associated with increased parenchymal $\mathrm{A} \beta$ and Tau levels $[25,26]$. ACE2 is reduced in AD in association with increased amyloid- $\beta$ and Tau [25]. Conversely, ACE2 overexpression reduces the brain $A \beta$-induced disease or ACE2 activation by diminazene aceturate improves the cognitive performance [27, 28] and ameliorates $A \beta$-induced inflammatory processes [29, 30]. In ACE2 knockout mice, the cognitive functions decrease [31].

Ang-(1-7) reduces the AD-related disease. Angiotensin(1-7) administration attenuates $\mathrm{AD}$ disease-like neuropathology in rats with streptozotocin-induced diabetes via Mas receptor activation [32]. Intracerebroventricular infusion of Angiotensin-(1-7) ameliorates cognitive impairment and memory Dysfunction in a AD mouse model [33]. Ang-(1-7) level is decreased in the plasma of AD patients [34] and in brain tissue of AD mice. Ang-(1-7) is reduced and there is an inverse relationship between Ang-(1-7) and Tau hyper-phosphorylation in AD animal models [35] which induces neurofibrillary tangles, a histopathological hallmark of AD. Moreover, AVE0991, a nonpeptide analogue of Ang-(1-7) attenuates aging-related neuroinflammation [36]. A novel Angiotensin-(1-7) glycosylated Mas receptor agonist has been used for treatment of inflammationrelated memory dysfunction cognitive impairment in a mouse model [37]. In rat neurons, side-chain-oxidized oxysterols upregulate the ACE2 expression level and Mas receptor [38]. The Ang-(1-7) / Mas receptor signaling is deceased in $\mathrm{AD}$ patients [23]. Ang (1-7) levels have been found to be reduced in cerebral cortex and hippocampus in an AD sporadic mouse model associated with hyperphosphorylation of Tau [35]. Furthermore, in $\mathrm{AD}$ patients, the plasma concentration of Ang-(1-7) is significantly reduced, suggesting that plasma Ang-(1-7) may represent a potential biomarker for $\mathrm{AD}$ diagnosis [34]. As the ACE2 gene expression is reduced in AD patients [25], the decrease in ACE2 expression level could protect against SARS-CoV-2 infection in $\mathrm{AD}$ and might partly account for the resilience observed in $\mathrm{AD}-\mathrm{SARS}-\mathrm{CoV}-2$ patients.

Taken together, these studies show that the ACE2 expression level is decreased in $\mathrm{AD}$ [39].

\section{CONCLUSIONS}

In conclusion, very young children get little COVID-19, probably partly due to the decreased expression of ACE2 at the nasal level. AD patients without associated co-morbidities seem relatively protected against SarsCoV-2 partly due to the decreased expression of ACE2 at the cerebral level. The determination of the nasal level of ACE2 gene expression could provide a useful scale to predict the susceptibility to contract the SARSCoV-2 infection. 


\section{CONFLICTS OF INTEREST}

The authors declare that they have no conflicts of interest.

\section{Editorial Note}

\&This corresponding author has a verified history of publications using the personal email address for correspondence.

\section{REFERENCES}

1. Donoghue $\mathrm{M}$, Hsieh $\mathrm{F}$, Baronas $\mathrm{E}$, Godbout $\mathrm{K}$, Gosselin M, Stagliano N, Donovan M, Woolf B, Robison $\mathrm{K}$, Jeyaseelan $\mathrm{R}$, Breitbart RE, Acton $\mathrm{S}$. A novel angiotensin-converting enzyme-related carboxypeptidase (ACE2) converts angiotensin I to angiotensin 1-9. Circ Res. 2000; 87:E1-9.

https://doi.org/10.1161/01.res.87.5.e1

PMID:10969042

2. Tipnis SR, Hooper NM, Hyde R, Karran E, Christie G, Turner AJ. A human homolog of angiotensinconverting enzyme. Cloning and functional expression as a captopril-insensitive carboxypeptidase. J Biol Chem. 2000; 275:33238-43.

https://doi.org/10.1074/ibc.M002615200 PMID:10924499

3. Baker SA, Kwok S, Berry GJ, Montine TJ. Angiotensinconverting enzyme 2 (ACE2) expression increases with age in patients requiring mechanical ventilation. PLOS One. 2021; 16:e0247060.

https://doi.org/10.1371/journal.pone.0247060 PMID:33592054

4. de Abajo FJ, Rodríguez-Martín S, Lerma V, Mejía-Abril G, Aguilar M, García-Luque A, Laredo L, Laosa O, Centeno-Soto GA, Ángeles Gálvez $M$, Puerro $M$, González-Rojano E, Pedraza L, et al, and MED-ACE2COVID19 study group. Use of renin-angiotensinaldosterone system inhibitors and risk of COVID-19 requiring admission to hospital: a case-population study. Lancet. 2020; 395:1705-14.

https://doi.org/10.1016/S0140-6736(20)31030-8 PMID:32416785

5. Yang J, Zheng Y, Gou X, Pu K, Chen Z, Guo Q, Ji R, Wang $\mathrm{H}$, Wang $\mathrm{Y}$, Zhou $\mathrm{Y}$. Prevalence of comorbidities and its effects in patients infected with SARS-CoV-2: a systematic review and meta-analysis. Int J Infect Dis. 2020; 94:91-95.

https://doi.org/10.1016/j.ijid.2020.03.017

PMID:32173574

6. Wijnant SR, Jacobs M, Van Eeckhoutte HP, Lapauw B, Joos GF, Bracke KR, Brusselle GG. Expression of ACE2, the SARS-CoV-2 Receptor, in Lung Tissue of Patients With Type 2 Diabetes. Diabetes. 2020; 69:2691-99. https://doi.org/10.2337/db20-0669 PMID:33024003

7. Fang L, Karakiulakis G, Roth M. Are patients with hypertension and diabetes mellitus at increased risk for COVID-19 infection? Lancet Respir Med. 2020; 8:e21.

https://doi.org/10.1016/S2213-2600(20)30116-8

PMID:32171062

8. Hoffmann $M$, Kleine-Weber $H$, Schroeder $S$, Krüger $N$, Herrler T, Erichsen S, Schiergens TS, Herrler G, Wu NH, Nitsche A, Müller MA, Drosten C, Pöhlmann S. SARSCoV-2 Cell Entry Depends on ACE2 and TMPRSS2 and Is Blocked by a Clinically Proven Protease Inhibitor. Cell. 2020; 181:271-80.e8. https://doi.org/10.1016/j.cell.2020.02.052 PMID: $\underline{32142651}$

9. Lan J, Ge J, Yu J, Shan S, Zhou H, Fan S, Zhang Q, Shi X, Wang $Q$, Zhang $L$, Wang $X$. Structure of the SARS-CoV-2 spike receptor-binding domain bound to the ACE2 receptor. Nature. 2020; 581:215-20. https://doi.org/10.1038/s41586-020-2180-5 PMID:32225176

10. Wang $Q$, Zhang $Y$, Wu L, Niu S, Song C, Zhang Z, Lu G, Qiao C, Hu Y, Yuen KY, Wang Q, Zhou H, Yan J, Qi J. Structural and Functional Basis of SARS-CoV-2 Entry by Using Human ACE2. Cell. 2020; 181:894-904.e9. https://doi.org/10.1016/j.cell.2020.03.045 PMID: 32275855

11. Vallée A, Lecarpentier $Y$, Vallée JN. Interplay of Opposing Effects of the WNT/B-Catenin Pathway and PPARY and Implications for SARS-CoV2 Treatment. Front Immunol. 2021; 12:666693. https://doi.org/10.3389/fimmu.2021.666693 PMID: 33927728

12. Duan $L$, Zheng $Q$, Zhang $H$, Niu $Y$, Lou $Y$, Wang $H$. The SARS-CoV-2 Spike Glycoprotein Biosynthesis, Structure, Function, and Antigenicity: Implications for the Design of Spike-Based Vaccine Immunogens. Front Immunol. 2020; 11:576622. https://doi.org/10.3389/fimmu.2020.576622 PMID: 33117378

13. Li W, Moore MJ, Vasilieva N, Sui J, Wong SK, Berne MA, Somasundaran M, Sullivan JL, Luzuriaga K, Greenough TC, Choe H, Farzan M. Angiotensin-converting enzyme 2 is a functional receptor for the SARS coronavirus. Nature. 2003; 426:450-54.

https://doi.org/10.1038/nature02145 PMID:14647384

14. Turner AJ, Hiscox JA, Hooper NM. ACE2: from vasopeptidase to SARS virus receptor. Trends 
Pharmacol Sci. 2004; 25:291-94. https://doi.org/10.1016/i.tips.2004.04.001 PMID:15165741

15. Santos RA, Sampaio WO, Alzamora AC, Motta-Santos D, Alenina N, Bader M, Campagnole-Santos MJ. The ACE2/Angiotensin-(1-7)/MAS Axis of the ReninAngiotensin System: Focus on Angiotensin-(1-7). Physiol Rev. 2018; 98:505-53.

https://doi.org/10.1152/physrev.00023.2016 PMID:29351514

16. Castagnoli R, Votto M, Licari A, Brambilla I, Bruno R, Perlini S, Rovida F, Baldanti F, Marseglia GL. Severe Acute Respiratory Syndrome Coronavirus 2 (SARS-CoV2) Infection in Children and Adolescents: A Systematic Review. JAMA Pediatr. 2020; 174:882-89. https://doi.org/10.1001/jamapediatrics.2020.1467 PMID:32320004

17. Wu Z, McGoogan JM. Characteristics of and Important Lessons From the Coronavirus Disease 2019 (COVID19) Outbreak in China: Summary of a Report of 72314 Cases From the Chinese Center for Disease Control and Prevention. JAMA. 2020; 323:1239-42.

https://doi.org/10.1001/jama.2020.2648 PMID: $\underline{32091533}$

18. Patel AB, Verma A. Nasal ACE2 Levels and COVID-19 in Children. JAMA. 2020; 323:2386-87.

https://doi.org/10.1001/jama.2020.8946 PMID:32432681

19. Bunyavanich S, Do A, Vicencio A. Nasal Gene Expression of Angiotensin-Converting Enzyme 2 in Children and Adults. JAMA. 2020; 323:2427-29.

https://doi.org/10.1001/jama.2020.8707

PMID:32432657

20. Dong $Y$, Mo X, Hu Y, Qi X, Jiang F, Jiang Z, Tong S. Epidemiology of COVID-19 Among Children in China. Pediatrics. 2020; 145:e20200702. https://doi.org/10.1542/peds.2020-0702 PMID:32179660

21. Li J, Long $X$, Huang $H$, Tang J, Zhu C, Hu S, Wu J, Li J, Lin Z, Xiong N. Resilience of Alzheimer's Disease to COVID19. J Alzheimers Dis. 2020; 77:67-73. https://doi.org/10.3233/JAD-200649 PMID:32804094

22. Gironacci MM, Vicario A, Cerezo G, Silva MG. The depressor axis of the renin-angiotensin system and brain disorders: a translational approach. Clin Sci (Lond). 2018; 132:1021-38. https://doi.org/10.1042/CS20180189 PMID:29802208

23. Wright JW, Harding JW. Contributions by the Brain Renin-Angiotensin System to Memory, Cognition, and Alzheimer's Disease. J Alzheimers Dis. 2019; 67:46980.

https://doi.org/10.3233/JAD-181035 PMID:30664507
24. Liu S, Liu J, Miura Y, Tanabe C, Maeda T, Terayama Y, Turner AJ, Zou K, Komano $\mathrm{H}$. Conversion of $A \beta 43$ to $A \beta 40$ by the successive action of angiotensinconverting enzyme 2 and angiotensin-converting enzyme. J Neurosci Res. 2014; 92:1178-86. https://doi.org/10.1002/jnr.23404 PMID:24823497

25. Kehoe PG, Wong S, Al Mulhim N, Palmer LE, Miners JS. Angiotensin-converting enzyme 2 is reduced in Alzheimer's disease in association with increasing amyloid- $\beta$ and tau pathology. Alzheimers Res Ther. 2016; 8:50.

https://doi.org/10.1186/s13195-016-0217-7 PMID:27884212

26. Tikhonova MA, Amstislavskaya TG, Belichenko VM, Fedoseeva LA, Kovalenko SP, Pisareva EE, Avdeeva AS, Kolosova NG, Belyaev ND, Aftanas LI. Modulation of the expression of genes related to the system of amyloid-beta metabolism in the brain as a novel mechanism of ceftriaxone neuroprotective properties. BMC Neurosci. 2018 (Suppl 1); 19:13. https://doi.org/10.1186/s12868-018-0412-5 PMID:29745864

27. Evans CE, Miners JS, Piva G, Willis CL, Heard DM, Kidd EJ, Good MA, Kehoe PG. ACE2 activation protects against cognitive decline and reduces amyloid pathology in the Tg2576 mouse model of Alzheimer's disease. Acta Neuropathol. 2020; 139:485-502.

https://doi.org/10.1007/s00401-019-02098-6

PMID:31982938

28. Kamel AS, Abdelkader NF, Abd El-Rahman SS, Emara M, Zaki HF, Khattab MM. Stimulation of ACE2/ANG(17)/Mas Axis by Diminazene Ameliorates Alzheimer's Disease in the D-Galactose-Ovariectomized Rat Model: Role of PI3K/Akt Pathway. Mol Neurobiol. 2018; 55:8188-202.

https://doi.org/10.1007/s12035-018-0966-3 PMID:29516284

29. Duan R, Xue X, Zhang QQ, Wang SY, Gong PY, E Y, Jiang $T$, Zhang YD. ACE2 activator diminazene aceturate ameliorates Alzheimer's disease-like neuropathology and rescues cognitive impairment in SAMP8 mice. Aging (Albany NY). 2020; 12:14819-29.

https://doi.org/10.18632/aging.103544 PMID:32701063

30. Fu X, Lin R, Qiu Y, Yu P, Lei B. Overexpression of Angiotensin-Converting Enzyme 2 Ameliorates Amyloid $\beta$-Induced Inflammatory Response in Human Primary Retinal Pigment Epithelium. Invest Ophthalmol Vis Sci. 2017; 58:3018-28.

https://doi.org/10.1167/iovs.17-21546

PMID:28605813

31. Wang XL, Iwanami J, Min LJ, Tsukuda K, Nakaoka H, Bai HY, Shan BS, Kan-No H, Kukida M, Chisaka T, Yamauchi 
T, Higaki A, Mogi M, Horiuchi M. Deficiency of angiotensin-converting enzyme 2 causes deterioration of cognitive function. NPJ Aging Mech Dis. 2016; 2:16024.

https://doi.org/10.1038/npjamd.2016.24

PMID:28721275

32. Chen JL, Zhang DL, Sun $Y$, Zhao YX, Zhao KX, Pu D, Xiao Q. Angiotensin-(1-7) administration attenuates Alzheimer's disease-like neuropathology in rats with streptozotocin-induced diabetes via Mas receptor activation. Neuroscience. 2017; 346:267-77.

https://doi.org/10.1016/i.neuroscience.2017.01.027

PMID:28147245

33. Uekawa K, Hasegawa Y, Senju S, Nakagata N, Ma M, Nakagawa T, Koibuchi N, Kim-Mitsuyama S. Intracerebroventricular Infusion of Angiotensin-(1-7) Ameliorates Cognitive Impairment and Memory Dysfunction in a Mouse Model of Alzheimer's Disease. J Alzheimers Dis. 2016; 53:127-33.

https://doi.org/10.3233/JAD-150642 PMID:27128367

34. Jiang T, Tan L, Gao Q, Lu H, Zhu XC, Zhou JS, Zhang YD. Plasma Angiotensin-(1-7) is a Potential Biomarker for Alzheimer's Disease. Curr Neurovasc Res. 2016; 13:96-99.

https://doi.org/10.2174/1567202613666160224124739 PMID:26907614

35. Jiang $T$, Zhang YD, Zhou JS, Zhu XC, Tian YY, Zhao HD, Lu H, Gao Q, Tan L, Yu JT. Angiotensin-(1-7) is Reduced and Inversely Correlates with Tau Hyperphosphorylation in Animal Models of Alzheimer's
Disease. Mol Neurobiol. 2016; 53:2489-97. https://doi.org/10.1007/s12035-015-9260-9 PMID:26044748

36. Jiang $T$, Xue $L$, Yang $Y$, Wang QG, Xue X, Ou Z, Gao Q, Shi JQ, Wu L, Zhang YD. AVE0991, a nonpeptide analogue of Ang-(1-7), attenuates agingrelated neuroinflammation. Aging (Albany NY). 2018; 10:645-57. https://doi.org/10.18632/aging.101419 PMID:29667931

37. Hay M, Polt R, Heien ML, Vanderah TW, Largent-Milnes TM, Rodgers K, Falk T, Bartlett MJ, Doyle KP, Konhilas JP. A Novel Angiotensin-(1-7) Glycosylated Mas Receptor Agonist for Treating Vascular Cognitive Impairment and Inflammation-Related Memory Dysfunction. J Pharmacol Exp Ther. 2019; 369:9-25.

https://doi.org/10.1124/ipet.118.254854

PMID:30709867

38. Mateos L, Ismail MA, Winblad B, Cedazo-Mínguez A. side-chain-oxidized oxysterols upregulate ACE2 and Mas receptor in rat primary neurons. Neurodegener Dis. 2012; 10:313-16. https://doi.org/10.1159/000333340 PMID:22236548

39. Oz M, Lorke DE. Multifunctional angiotensin converting enzyme 2, the SARS-CoV-2 entry receptor, and critical appraisal of its role in acute lung injury. Biomed Pharmacother. 2021; 136:111193.

https://doi.org/10.1016/i.biopha.2020.111193 PMID:33461019 